\title{
PENERAPAN PRINSIP ULTRA PETITA DALAM HUKUM ACARA PIDANA DIPANDANG DARI ASPEK PERTIMBANGAN HUKUM PUTUSAN PERKARA PIDANA
}

\author{
Yagie Sagita Putra \\ Fakultas Hukum Universitas Diponegoro \\ Email : yagie_88@yahoo.co.id
}

\begin{abstract}
Ultra petita, where the judge ruled on the case were not prosecuted or graduated more than requested, in other words, is the imposition of an ultra petita ruling by the judge on a case that is not required or exceed mememutus than requested. In the context of the Code of Criminal Procedure, the verdict was issued, because the public prosecutor charges less than perfect, and as an expression of the progressive development of the law in which the judge not only as the mouthpiece of the law but it is the mouthpiece of justice capable of providing a quality decision to locate the source of the law.

That the judge's ruling should not be guided by the law as the procedure is absolute because if the judge's decision only based procedure, the spirit and ideals of the Criminal Law (Law of Material) and the Criminal Law (Law Formal) contained in the principles of the law will not be realized. This does not mean that there are legal procedures in the legislation do not need to be implemented but must be applied intelligently and wisely, and hoped all parties to be more critical in addressing the development of the law for the sake of the common good. To investigate this problem the authors tried to analyze the jurisprudence of the Supreme Court NO. 675 K / Pid / 1987 dated 21-03-1989 and the Corruption Court decision No. 17 / PID.SUS / TPK / 2014 / PN.JKT.PST. associated with the Criminal Procedure Code, using the study of philosophical and juridical terms.
\end{abstract}

Keywords: Ultra Petita; Legal; Considerations; Criminal

\begin{abstract}
ABSTRAK
Ultra petita, demikian istilahnya, dimana hakim menjatuhkan putusan atas perkara yang tidak dituntut atau meluluskan lebih dari pada yang diminta, dengan kata lain ultra petita adalah penjatuhan putusan oleh hakim atas perkara yang tidak dituntut atau mememutus melebihi dari pada yang diminta. Dalam konteks Hukum Acara Pidana, Putusan tersebut dikeluarkan, dikarenakan dakwaan Jaksa Penuntut Umum kurang sempurna dan sebagai wujud pengembangan hukum progresif dimana Hakim bukan hanya sebagai corong undang-undang tetapi merupakan corong keadilan yang mampu memberikan putusan yang berkualitas dengan menemukan sumber hukum yang tepat.

Bahwa putusan hakim tidak harus berpedoman pada undang-undang sebagai prosedur mutlak sebab bila putusan hakim hanya berlandaskan prosedur, maka roh dan citacita dari Hukum Pidana (Hukum Materiil) maupun Hukum Acara Pidana (Hukum Formil) yang tertuang dalam asas-asas hukum tersebut tidak akan bisa diwujudkan. Hal ini bukan berarti prosedur hukum yang ada dalam undang-undang tidak perlu dilaksanakan tetapi harus diterapkan secara cerdas dan bijaksana, serta diharapkan semua pihak agar lebih kritis dalam menyikapi perkembangan hukum demi kesejahteraan bersama. Untuk meneliti permasalahan ini penulis berusaha menganalisis Yurisprudensi
\end{abstract}


Mahkamah Agung NO. 675 K/Pid/1987, tanggal 21-03-1989 dan putusan Pengadilan Tindak Pidana Korupsi Nomor : 17/PID.SUS/TPK/2014/PN.JKT.PST. dikaitkan dengan Hukum Acara Pidana, dengan menggunakan kajian dari segi filosofis dan yuridis.

\section{Kata kunci : Ultra Petita; Pertimbangan Hukum; Pidana}

\section{Pendahuluan}

Putusan hakim merupakan "puncak" dari pemeriksaan perkara pidana dalam keseluruhan proses peradilan pidana. Dalam putusan hakim diharapkan akan ditemukan pencerminan nilai-nilai keadilan dan kebenaran hakiki, hak asasi manusia, penguasaan hukum dan fakta secara mapan, mumpuni dan faktual. Putusan hakim mencerminkan visualisasi etika, mentalitas, moralitas hati nurani hakim, serta dapat dipertanggungjawabkan kepada justiabelen, ilmu hukum/doktrin hukum, masyarakat dan "Demi Keadilan Berdasarkan Ketuhanan Yang Maha Esa”.

Putusan Hakim sebagai proses akhir dalam penegakan hukum merupakan kegiatan yang paling problematis, dilematis dan mempunyai tingkat kontroversi yang tinggi. Upaya untuk mencari, menemukan dan menerapkan hukum inilah yang kerapkali menimbulkan rasa tidak puas terhadap para pihak hingga di kalangan masyarakat. Dasar pertimbangan hakim dalam menjatuhkan pidana akan sangat menentukan apakah putusan seorang hakim dianggap adil atau menentukan apakah putusannya dapat dipertanggungjawabkan atau tidak.
Disamping itu putusan pengadilan yang dijatuhkan oleh hakim harus berdasarkan kepada surat dakwaan yang dibuat oleh Jaksa Penuntut Umum yang berisi fakta-fakta yang terjadi dalam suatu tindak pidana (delik) beserta aturan-aturan hukum yang dilanggar oleh terdakwa.

Penuntut Umum harus teliti dan cermat dalam membuat isi daripada surat dakwaan, dimana harus memenuhi baik syarat formil maupun materil surat dakwaan tersebut seperti yang disebutkan di dalam Pasal 184 ayat (2) KUHAP. Surat dakwaan akan menjadi dasar bagi pemeriksaan di persidangan dan pengambilan keputusan oleh hakim. Dengan kata lain, putusan hakim di dalam perkara pidana dibatasi oleh apa yang didakwakan jaksa penuntut umum, sama dengan perkara perdata dibatasi pula oleh apa yang digugat oleh pengugat. Namun dalam prakteknya ditemukan banyak putusan perkara pidana yang diputus oleh hakim diluar dari dakwaan dan atau tuntutan yang diajukan penuntut umum, hal tersebut berawal dari adanya penafsiran yang berbeda dalam menganalisa perkara, baik dalam proses pembuktian hingga penerapan pasal yang akan diterapkan. Adapaun putusan 
tersebut adalah Putusan Pengadilan Tindak Pidana Korupsi Jakarta Pusat yang mengadili perkara Nomor 17/PID.SUS/TPK/2014/PN.JKT.PST tanggal 12 Februari 2014, dalam perkara terdakwa Susi Tur Handayani telah menjatuhkan putusan dengan menyatakan bersalah serta menghukum para terdakwa dengan putusan di luar dakwaan Jaksa Penuntut Umum.

Menurut Penulis ada penyimpangan terhadap penerapan Pasal 191 ayat (1) KUHAP yang menyatakan : "Jika pengadilan berpendapat bahwa dari hasil pemeriksaan di sidang pengadilan, kesalahan terdakwa atas perbuatan yang didakwakan kepadanya tidak terbukti secara sah dan menyakinkan, maka terdakwa diputus bebas". Kenyataannya Majelis Hakim yang mengadili perkara tersebut tidak melaksanakan ketentuan yang tercantum dalam Pasal 191 ayat (1) KUHAP, akan tetapi dengan berpijak pada Yurisprudensi putusan MA No. 675 K/pid/ 1987, tgl 21-031989 sebagai dasar hukum telah menjatuhkan putusan berupa menyatakan bersalah serta menghukum terdakwa dengan putusan di luar dakwaan Jaksa penuntut Umum.

Dalam beberapa putusan Mahkamah Konstitusi hal tersebut dikenal dengan istilah Ultra petita, demikian istilahnya, dimana hakim menjatuhkan putusan atas perkara yang tidak dituntut atau meluluskan lebih dari pada yang diminta, dengan kata lain ultra petita adalah penjatuhan putusan oleh hakim atas perkara yang tidak dituntut atau mememutus melebihi dari pada yang diminta.

Dari banyaknya perdebatan tentang berlakunya ultra petita, salah satu hakim yang menerapkan prinsip ultra petita dalam hukum acara pidana yakni Bagir Manan menyatakan bahwa Putusan Ultra Petita boleh dilakukan, dengan syarat dalam petitum subsidair harus tercantum permohonan Ex aequo et bono atau "Jika Hakim berpendapat lain, mohon putusan yang seadil-adilnya (atau kalimat yang senada dengan itu)". ${ }^{1}$

Sehingga untuk mencari solusi hukum dari beberapa pemasalahan tersebut, maka penulis merasa perlu untuk mengadakan penelitian dengan judul "Penerapan Prinsip Ultra Petita Dalam Hukum Acara Pidana Dipandang Dari Aspek Pertimbangan Hukum Putusan Perkara Pidana”.

\section{Metode Penelitian}

Rencana penelitian tesis ini tergolong ke dalam penelitian hukum normatif, yaitu "Penelitian hukum yang dilakukan dengan cara meneliti bahan pustaka atau data sekunder belaka. ${ }^{2}$ Menurut Soerjono Soekanto dan Sri Mamudji, mengenai

1 Dalam http://fatahilla.blogspot.com/2008/06/ultrapetita-mahkamah-konstitusi.html, diakses pada tanggal 22 Agustus 2015

${ }^{2}$ Soerjono Soekanto, Sri Mamudji, Penelitian Hukum Normatif Suatu Tinjauan Singkat, Penerbit: PT. Raja Grafindo Persada, Jakarta, 2004, hlm. 13-14. 
penelitian hukum normatif atau kepustakaan tersebut mencakup hal-hal, sebagai berikut: ${ }^{3}$

a. Penelitian terhadap asas-asas hukum.

b. Penelitian terhadap sistimatik hukum.

c. Penelitian terhadap taraf sinkronisasi vertikal dan horizontal.

d. Perbandingan hukum.

e. Sejarah hukum.

Terkait dengan klasifikasi tersebut di atas, penelitian tesis ini dilakukan dengan pendekatan yuridis normatif yang menyangkut penelitian dengan perbandingan hukum. Perbandingan hukum dilakukan dengan cara menetapkan satu atau beberapa masalah yang dianggap paling penting untuk diteliti. $^{4}$

\section{Kerangka Teori}

a. Asas-asas hukum pidana

Asas-asas hukum acara pidana diatur dalam Undang-Undang Nomor 14 Tahun 1970 jo Undang-Undang Nomor 35 Tahun 1999 jo UndangUndang Nomor 4 Tahun 2004 jo Undang-Undang Nomor 48 Tahun 2009 tentang kekuasaan kehakiman dan Undang-undang Nomor 8 Tahun 1981 tentang Kitab Undang-Undang Hukum Acara Pidana (KUHAP), yaitu sebagai berikut :

1) Asas peradilan cepat, sederhana dan biaya ringan.

2) Asas Principle of Legality.
3) Asas Pemeriksaan Perkara Pidana dengan Kehadiran Terdakwa

4) Asas praduga tidak bersalah (Presumption of Innocence).

5) Asas Hak Ingkar.

6) Asas Pemeriksaan Pengadilan Terbuka untuk Umum

7) Asas Perlakuan yang Sama Bagi Setiap Orang di Depan Hukum (Equality before The Law).

8) Asas Bantuan Hukum

9) Asas Ganti Rugi dan Rehabilitasi

10) Asas pengawasan dan pengamatan pelaksanaan putusan pengadilan.

Berdasarkan asas-asas hukum acar pidana di atas, maka aparat penegak hukum dalam menegakan hukum harus memperhatikan asas-asas yang ada di dalam hukum pidana dan yang berlaku secara intenasional. Hal ini berarti, penegak hukum juga harus memperhatikan asas-asas hukum acara pidana.

b. Asas-Asas Pertimbangan Hukum dalam Putusan Perkara Pidana.

Menurut Gustav Radbruch, hukum mempunyai 3 (tiga) nilai dasar, yaitu keadilan, kemanfaatan dan kepastian hukum. Selanjutnya Gustav Radbruch mengajarkan penggunaan asas prioritas dari ketiga asas tersebut, antara lain : keadilan merupakan

\footnotetext{
${ }^{3}$ Ibid, hlm: 14

${ }^{4}$ Ibid, hlm: 14
} 
prioritas pertama, kemudian kemanfaatan dan terakhir kepastian hukum. ${ }^{5}$

Hakim dalam memutuskan perkara secara kasuistis selalu di hadapkan pada ketiga asas, antara lain : 6

1) Asas Kepastian Hukum.

2) Asas Keadilan.

3) Asas Kemanfaatan.

Menurut Sudikno Mertokusumo, ketiga asas tersebut harus dilaksanakan secara kompromi, yaitu dengan cara menerapkan ketiga-tiganya secara berimbang atau proporsional, sehingga tidak perlu mengikuti asas prioritas sebagaimana yang dikemukakan oleh Gustav Radbruch. Akan tetapi seharusnya mengikuti asas prioritas yang kasuistis dan sesuai dengan kasus yang dihadapi. $^{7}$

Berdasarkan praktik peradilan, hakim harus memilih salah satu dari ketiga asas tersebut untuk memutus suatu perkara dan tidak mungkin ketiga asas tersebut untuk memutus suatu perkara dan tidak mungkin ketiga asas tersebut dapat tercakup sekaligus dalam satu putusan (asas prioritas yang kasuistis). Apabila diibaratkan dalam sebuah garis, hakim dalam memeriksa dan memutuskan suatu perkara berada di antara 2

\footnotetext{
${ }^{5}$ Achmad Ali, Menguak Tabir Hukum (Suatu Kkajian Filosofis dan Sosiologis), Penerbit : Chandra Pratama, Jakarta, 1993, hlm. 50

${ }^{6}$ Ahmad Rifai, Penemuan Hakim oleh Hakim Dalam Perspektif Hukum Progresif, Penerbit : Sinar Grafika, Jakarta, 2010, hlm. 132

7 Sudikno Mertokusumo dan A. Pitlo, Bab-bab Tentang Penemuan Hukum, Penerbit : Citra Aditya Bakti, Jakarta, 1993, hlm. 2
}

(dua) titik pembatas dalam garis tersebut, yaitu apakah berdiri pada titik keadilan atau titik kepastian hukum, sedangkan titik kemanfaatan berada di antara kedua titik tersebut. $^{8}$

Pada saat hakim menjatuhkan putusan yang lebih dekat mengarah kepada asas kepastian hukum, maka secara otomatis, hakim akan menjauh dari titik keadilan. Sebaliknya, kalau hakim menjatuhkan putusan lebih dekat mengarah kepada keadilan, maka secara otomatis pula hakim akan menjauhi titik kepastian hukum. Sehingga batas-batas kebebasan hakim hanya dapat bergerak di antara 2 (dua) titik pembatas tersebut. Hakim dalam memeriksa dan menjatuhkan putusan suatu perkara bersifat bebas dan tanpa batas.

\section{c. Teori Penemuan Hukum.}

Peraturan Perundang-undangan merupakan hukum buatan manusia yang terkadang bersifat tidak jelas, tidak lengkap, bersifat statis ddan tidak dapat mengetahui perkembangan masyarakat sehingga hal ini menimbulkan ruang kosong dan harus diisi oleh hakim dengan menemukan hukumnya yang dilakukan dengan cara menjelaskan, menafsirkan atau melengkapi peraturan perundang-undangannya.

\footnotetext{
${ }^{8}$ Ahmad Rifai, Penemuan Hakim oleh Hakim Dalam Perspektif Hukum Progresif, Penerbit : Sinar Grafika, Jakarta, 2010, hlm. 127-129
} 
Penemuan hukum oleh hakim tidak semata-mata menyangkut penerapan peraturan perundang-undangan terhadap peristiwa konkret, tetapi juga penciptaan hukum dan pembentukan hukumnya sekaligus. $^{9}$

Menurut Achmad Ali, ada 2 (dua) teori penemuan hukum yang dapat dilakukan oleh hakim dalam praktik peradilan, yaitu melalui metode interpretasi atau penafsiran dan melalui metode konstruksi. ${ }^{10}$

\section{d. Teori Penjatuhan Putusan.}

Kekuasaan kehakiman merupakan badan yang menentukan isi dan kekuatan kaidah-kaidah hukum positif dalam konkretisasi oleh hakim melalui putusanputusannya. Fungsi utama dari seorang hakim adalah memberikan putusan terhadap perkara yang diajukan kepadanya, dimana dalam perkara pidana hakim memeriksa dan memutus perkara menggunakan sistim pembuktian negatif (negative wetterlijke). ${ }^{11}$

Menurut Mackenzie, ada beberapa teori atau pendekatan yang dipergunakan oleh hakim dalam mempertimbangkan penjatuhan putusa dalam suatu perkara, yaitu sebagai berikut: ${ }^{12}$

1) Teori Keseimbangan.

9 Jazim Hamidi, Hermeunetika Hukum, Teori Penemuan Hukum Baru dengan Interpretasi Teks, Penerbit : UII Press, Yogyakarta, 2005, hlm : 52.

${ }^{10}$ Achmad Ali, Op Cit, hlm : 167

${ }^{11}$ Ahmad Rifai, Op Cit, hlm. 102-103

12 Bagir Manan, Hakim dan Pemidanaan, Majalah Hukum Varia Peradilan Edisi No. 249 Bulan Agustus 2006, Ikahi, Jakarta, 2006, hlm. 7-12
2) Teori Pendekatan Seni dan Intuisi.

3) Teori Pendekatan Keilmuan.

4) Teori Pendekatan Pengalaman.

5) Teori Ratio Decidendi.

6) Teori Kebijaksanaan.

\section{Hasil Penelitian dan Pembahasan}

\section{Kebijakan Penerapan Prinsip Ultra} Petita Dalam Putusan Perkara Pidana Pada Saat Ini

Fakta hukum menyangkut ultra petita yang diterapkan dalam putusan perkara pidana merupakan penerobosan aturan hukum acara pidana. Dengan adanya ultra petita ini, maka diperlukan mengenai suatu kajian tentang pemberlakuan ultra petita dalam proses persidangan perkara pidana.

Berikut penulis sajikan perkara pidana serta kajian yuridis mengenai perkara pidana yang menggunakan prinsip ultra petita dalam putusan.

Perkara pidana nomor 17/PID.SUS/TPK/2014/PN.JKT.PST

merupakan salah satu perkara tindak pidana korupsi di sidangkan di Pengadilan Tindak Pidana Korupsi Jakarta.

Dalam menyatakan kesalahan terdakwa tersebut, majelis hakim mempertimbangkan bahwa perbuatan terdakwa telah memenuhi semua unsur tindak pidana Pasal 6 ayat (1) huruf a Undang-undang Nomor 31 Tahun 1999 tentang Pemberantasan Tindak Pidana Korupsi sebagaimana telah diubah dengan Undang-undang Nomor : 20 Tahun 2001 
tentang Perubahan atas Undang-undang Nomor 31 tahun 1999 tentang Pemberantasan Tindak Pidana Korupsi jo. Pasal 55 ayat(1) ke-1 KUHP DAN pasal 13 Undang-undang Nomor 31 Tahun 1999 tentang Pemberantasan Tindak Pidana Korupsi sebagaimana telah diubah dengan Undangundang Nomor : 20 Tahun 2001 tentang Perubahan atas Undang-undang Nomor 31 tahun 1999 tentang Pemberantasan Tindak Pidana Korupsi jo pasal 64 ayat 1 KUHP. Sealanjutya, selama persidangan berlangsung tidak ditemukan alasan pembenar maupun pemaaf yang dapat dijadikan dasar penghapusan kesalahan terdakwa. Selain itu, alat bukti yang diajukan dipersidangan terdapat hubungan yang berkaitan erat satu dengan yang lainnya. Sehingga majelis hakim memperoleh keyakinan bahwa benar telah terjadi tindak pidana dan terdakwalah bersalah melakukannya. Berdasarkan Pasal 193 ayat (1) KUHAP, maka cukup alasan bagi pengadilan untuk menjatuhkan pidana kepada terdakwa tersebut.

Berdasarkan fakta-fakta hukum di atas, menurut Majelis Hakim, Dakwaan Pertama dan Dakwaan kedua tidak dapat diterapkan kepada diri terdakwa. sekalipun Penuntut Umum mendakwa Terdakwa dalam melakukan perbuatannya bersamasama dengan M. Akil Mochtar yang adalah seorang Hakim Konstitusi, namun Majelis Hakim berpendapat kualifikasi subyek hukum dalam pasal 12 huruf c pertama- tama haruslah seorang hakim yang memutus perkara yang diterimanya untuk diadili.

Seseorang yang tidak pernah menerima dan memutus suatu perkara untuk diadili tidak dapat didakwa dengan menggunakan pasal 12 huruf c. Dalam membuktikan bersalah tidaknya Terdakwa melakukan perbuatan yang didakwakan, pertama-tama harus dibuktikan apakah perbuatan terdakwa memenuhi unsur pidana pokok (bestandeel delict). akan tetapi meskipun perbuatan Terdakwa tidak memenuhi unsur pasal yang didakwakan oleh Penuntut Umum, dan oleh karenanya harus dibebaskan dari dakwaan pasal tersebut, namun berdasarkan fakta-fakta hukum yang terungkap di persidangan, Majelis Hakim akan mempertimbangkan perbuatan terdakwa berdasarkan pasal yang menurut Majelis Hakim lebih tepat diterapkan pada diri terdakwa dengan alasanalasan hukum sebagai berikut:

1) Bahwa berdasarkan fakta fakta hukum yang terungkap dipersidangan telah ternyata atau dapat disimpulkan adanya perbuatan pidana yang dilakukan terdakwa.

2) Bahwa kalaupun pasal-pasal Tindak Pidana yang didakwakan Penuntut Umum dipandang kurang tepat diterapkan bagi terdakwa dan selanjutnya Majelis Hakim 
berpendapat pasal pasal tindak pidana yang akan diterapkan dipandang lebih cocok diterapkan bagi terdakwa sesuai fakta fakta hukum yang terungkap dipersidangan adalah karena dianggap antara pasal pasal tindak pidana yang didakwakan Penuntut Umum dengan pasal pasal tindak pidana yang akan diterapkan tersebut tidak terlalu menyimpang bahkan dapat dikatakan antara pasal pasal tersebut adalah saling berpasangan misalnya antara pasal 12 huruf $\mathrm{c}$ dengan pasal 6 ayat (1) huruf a adalah berpasangan dan dapat juga disebut berpasangan dengan pasal 13 dan pasal-pasal tersebut sama sama termasuk dalam BAB II tentang Tindak Pidana Korupsi tentang penyuapan dalam Undang undang No. 31 tahun 1999 sebagaimana telah diubah dengan Undang Undang No. 20 tahun 2001 tentang perubahan atas Undang Undang Republik Indonesia Nomor 31 tahun 1999 tentang Pemberantasan Tindak Pidana Korupsi.

3) Bahwa jika dalam dakwaan unsur Hakim dikaitkan dengan terdakwa dalam kapasitasnya turut serta, maka dalam pasal 6 ayat (1) huruf a dan pasal 13 maka subjek pelakunya langsung ditujukan kepada terdakwa karena terdakwa bukanlah seorang Hakim melainkan orang perseorangan yang bekerja sebagai Advokat.

4) Bahwa pasal 6 ayat (1) huruf a dan pasal 13 substansinya pada hakekatnya berada juga di dalam pasal 12 huruf $\mathrm{C}$ jo pasal 55 ayat(1) ke 1 KUHP.

5) Bahwa pasal pidana yang akan diterapkan bagi terdakwa dipandang tidak merugikan terdakwa karena ancaman pidananya lebih rendah dari ancaman pidana pasal yang didakwakan.

6) Bahwa dalam perkara aquo Majelis memperhatikan kepentingan pemberantasan tindak pidana korupsi yang menjadi perhatian masyarakat luas sesuai azas kemanfaatan, kepatutan dan keadilan.

\section{Dasar Hukum Hakim} Menjatuhkan Putusan Berdasarkan Prinsip Ultra Petita

a. Yurisprudensi sebagai dasar hakim memutus di luar dakwaan (Berdasarkan Prinsip Ultra Petita)

Di dalam perkara pidana, dasar pemeriksaan sidang pengadilan adalah surat dakwaan. Pengadilan menjatuhkan putusan berdasarkan fakta-fakta yang terungkap dalam pemeriksaan sidang yang didasarkan pada surat dakwaan tersebut. Oleh 
karena itu, pengadilan tidak dibenarkan untuk memutus hal-hal yang tidak didakwakan dalam surat dakwaan.

Djoko Prakoso menyatakan: "Dapat dikatakan bahwa salah satu asas yang paling fundamental dalam proses pidana adalah keharusan pembuatan surat dakwaan. Ia memuat fakta-fakta yang didakwakan terhadap seorang terdakwa dan hakim hanya boleh memutuskan atas dasar faktafakta tersebut, tidak boleh kurang atau lebih. Oleh sebab itu, surat dakwaan dipandang sebagai suatu litis contestatio ."13

Namun demikian, perlu pula diingat bahwa yurisprudensi merupakan salah satu sumber hukum. Bahkan dalam perkembangan praktek peradilan dewasa ini yurisprudensi telah menempatkan diri pada posisi yang sangat dominan dalam mengisi ruang-ruang kosong yang tidak terjangkau oleh pengaturan hukum melalui undang-undang. Yurisprudensi sebagai putusan pengadilan pada tingkat peradilan tertinggi, akan mewarnai praktek peradilan. Karena yurisprudensi memecahkan permasalahan-

\footnotetext{
${ }^{13}$ Litis contestatio adalah istilah yang digunakan merujuk kepada dasar hakim untuk menjatuhkan putusan terhadap suatu perkara.
}

permasalahan hukum yang ditemukan dalam praktek. Hakim di depan persidangan melakukan pemeriksaan terhadap terdakwa berdasarkan surat dakwaan dari Penuntut Umum. Pada hakikatnya, hakim tidak boleh merubah surat dakwaan sebagaimana ditentukan Putusan Mahkamah Agung Republik Indonesia Nomor 589 K/Pid/1984 tanggal 17 Oktober 1984 dan hakim juga dalam menjatuhkan hukuman kepada terdakwa tidak diperkenankan menjatuhkan pidana terhadap perbuatan yang tidak didakwakan oleh Penuntut Umum dalam surat dakwaannya sebagaimana ditentukan Putusan Mahkamah Agung Republik Indonesia Nomor $321 \mathrm{~K} / \mathrm{Pid} / 1983$ taggal $26 \mathrm{Mei}$ 1984. Selain itu, dalam putusan Mahkamah Agung Nomor 47 $\mathrm{K} / \mathrm{Kr} / 1956$ tanggal 23 Maret1957 dan Nomor 68 K/Kr/1973 tanggal 16 Desember 1976 ditegaskan bahwa putusan pengadilan harus didasarkan pada tuduhan (dakwaan).

Akan tetapi, terhadap hal ini ada perkembangan menarik dan merupakan terobosan baru dari Mahkamah Agung RI. Terdapat beberapa putusan pengadilan yang memutus suatu tindak pidana yang secara tegas tidak dirumuskan dalam surat dakwaan dapat dibenarkan, apabila 
tindak pidana yang dinyatakan terbukti tersebut sejenis dengan tindak pidana yang didakwakan (yang dirumuskan secara tegas dalam surat dakwaan).

b. Tujuan dikeluarkannya

Yurisprudensi MA NO. 675 K/Pid/1987, tanggal 21-03-1989

Satjipto Rahardjo menyatakan bahwa yuriprudensi MA No. 675 $\mathrm{K} / \mathrm{Pid} / 1987$, tanggal 21-03-1989 sebagai salah satu sumber peraturan hukum harus ditemukan esensi yang terkandung di dalam isinya dengan meninjau kepada asas-asas hukum, baik asas yang terkandung dalam Pancasila, Undang-Undang Dasar 45, Hukum Pidana, dan terutama Hukum Acara Pidana karena yurisprudensi tersebut mengatur tentang dapat dijatuhkannnya putusan diluar dakwaan yang diajukan Jaksa Penuntut Umum. Dimana surat dakwaan adalah salah satu dasar dalam proses beracara di pengadilan pidana. $^{14}$

Adapun isi dari Yurisprudensi MA No. 675 K/Pid/1987, tanggal 2103-1989. adalah sebagai berikut : "Jika yang terbukti adalah delict sejenis yang lebih ringan sifatnya dari delict sejenis yang didakwakan

14 Satjipto Rahardjo, Biarkan Hukum Mengalir, Catatan Kritis tentang Pergulatan Manusia dan Hukum, (Jakarta: Penerbit Buku Kompas, 2007), hlm. 20 yang lebih berat sifatnya, maka meskipun delictyang lebih ringan tersebut tidak didakwakan, maka terdakwa dapat dipersalahkan dipidana atas dasar melakukan delict yang lebih ringan tersebut."

Dari yurisprudensi tersebut apabila dikaitkan dengan asas atau tujuan hukum yang secara umum adalah untuk memelihara kepentingan umum dalam masyarakat, menjaga hak-hak manusia, serta mewujudkan keadilan dalam hidup bersama dan tidak lupa asas pokok dalam hukum acara pidana sendiri yaitu asas peradilan cepat, sederhana dan biaya ringan (Contante justitie), yang tertuang dalam Penjelasan Umum KUHAP butir 3e dan dijabarkan dalam banyak Pasal KUHAP, serta dalam Pasal 4 ayat (2) Undang-Undang No.4 Tahun 2004. Maka dapat di simpulkan isi dari yurisprudensi MA tersebut memiliki korelasi yang kuat serta searah dengan tujuan dari hukum dan asas pokok hukum acara pidana dengan logika penjabaran sebagai berikut : Bahwa dikeluarkannya yurisprudensi MA No. 675 K/Pid/1987, tanggal 21-03-1989. akan lebih memudahkan pengadilan dalam melaksanakan pemeriksaan secara cepat, sederhana dan biaya ringan dengan tetap menjunjung tinggi 
keadilan serta kemanusian. Yaitu apabila didalam proses pemeriksaan dalam persidangan unsur-unsur tindak pidana yang didakwakan ada yang tidak terbukti secara sah dan menyakinkan maka terdakwa harus diputus bebas (Pasal 191 ayat (1) KUHAP), namun disisi lain unsurunsur lain yang telah dapat dibuktikan dalam sidang pengadilan sudah memenuhi rumusan dalam Kitab Undang-Undang Hukum Pidana yang merupakan delik sejenis dan ancaman hukumanya lebih ringan dari delik yang di cantumkan dalam surat dakwaan maka terdakwa tetap dapat dijatuhi pidana berdasarkan delik yang sejenis yang lebih ringan tersebut walaupun tidak dicantumkan dalam surat dakwaan.

Jika Majelis hakim yang memeriksa dan memutus perkara yang demikian, hanya mengacu pada aturan KUHAP dalam Pasal 191 ayat (1) maka terdakwa harus di putus bebas padahal diketahui dan telah terbukti secara sah dan menyakinkan bahwa terdakwa telah melakukan tindak pidana walaupun tidak tercantum dalam surat dakwaan jaksa Penuntut Umum. Bila telah diputus bebas Majelis Hakim dan Jaksa tidak akan membiarkan terdakwa keluar dari tahanan sebab itu berarti Majelis
Hakim dan Jaksa Penuntut Umum telah meninggalkan tugasnya yang sebagai aparat penegak hukum serta mengabaikan tujuan dari hukum acara pidana yang paling hakiki yaitu menemukan kesalahan yang memenuhi syarat undang-undang pidana serta menjatuhkan putusan berupa sanksi pidana kepada pelaku. Secara logika setelah diputus bebas maka Jaksa Penuntut Umum akan mengajukan dakwaan baru kepada Pengadilan sesuai dengan yang telah terbukti dalam persidangan sebelumnya yaitu delik sejenis yang lebih ringan ancaman hukumannya hal ini akan sangat merugikan bagi semua pihak. Dikatakan merugikan karena :

a. Bagi terdakwa secara otomatis masa penahannya akan diperpanjang hingga batas yang paling akhir, untuk menunggu persidangan ulangan. Sedangkan apabila sudah diputus dalam sidang sebelumnya terdakwa tidak perlu lagi menjalani proses penahanan atau dapat langsung menjalankan masa hukuman. Juga berkaitan biaya yang harus dikeluarkan untuk penasehat hukum.

b. Bagi korban dan keluarganya, keadilan yang diharapkan segera terwujud dengan dikeluarkannya 
putusan akan menjadi tertunda sehingga dapat menambah penderitaan.

c. Bagi hakim dan jaksa, hakim dan jaksa harus melakukan pemeriksaan ulang dalam persidangan yang secara otomatis akan menyita waktu dan tenaga padahal unsurunsur dakwaan yang baru telah nyata-nyata terbukti secara sah dan menyakinkan pada persidangan sebelumnya.

d. Bagi masyarakat, terutama masyarakat pencari keadilan di wilayah hukum yang bersangkutan mereka harus menunggu lebih lama untuk menjalani persidangan karena hakim dan jaksa masih disibukkan dengan perkara yang sebenarnya telah diperiksa sebelumnya.

e. Bagi negara, akan membuat beban negara lebih besar karena biaya yang dikeluarkan untuk persidangan ulang.

Sudah jelas bahwa tujuan dikeluarkannya Yurisprudensi MA No. 675 K/Pid/1987, tanggal 21-03-1989 adalah dalam rangka mewujudkan keadilan dan kemanusiaan dalam masyarakat serta selaras dengan asas hukum acara pidana khususnya asas peradilan cepat, sederhana, dan biaya ringan.

\section{Formulasi Prinsip Ultra Petita Dalam Pembaharuan Kitab Hukum Acara Pidana}

Dalam penjelasan umum RKUHAP dikemukakan sejumlah indikator yang menunjukkan KUHAP sudah ketinggalan zaman. Pertama, KUHAP masih belum mampu memenuhi kebutuhan hukum dalam masyarakat, terutama dalam praktik penanganan perkara tindak pidana yang menjadi tugas para penegak hukum untuk menyelesaikan perkaranya secara baik dan adil. Kedua, perkembangan hukum dan perubahan peta politik yang dibarengi dengan perkembangan ekonomi, transportasi, dan teknologi yang global berpengaruh pula terhadap makna dan keberadaan substansi KUHAP.

Berkenaan dengan dasar hukum yang digunakan hakim dalam menjatuhkan putusan di luar pasal yang didakwakan oleh Penuntut Umum adalah melalui yurisprudensi MA No. 675 K/Pid/1987, tanggal 21-03-1989. Sementara itu, bila dilihat pada Pasal 182 ayat (4) dan Pasal 191 ayat (1) KUHAP, maka hukum acara pidana di Indonesia menyatakan bahwa putusan yang dijatuhkan hakim haruslah berdasarkan kepada surat dakwaan yang dibuat oleh Penuntut Umum. Jika pasal-pasal yang didakwakan Penuntut Umum dalam surat dakwaannya tidak terbukti di persidangan, maka terdakwa diputus bebas. Hal ini tentu menimbulkan 
kegamangan di dalam memahami hukum acara pidana di Indonesia.

Pasal 191 (1) KUHAP menentukan: "Jika pengadilan berpendapat bahwa dari hasil pemeriksaan di sidang, kesalahan terdakwa atas perbuatan yang didakwakan kepadanya tidak terbukti secara sah dan meyakinkan, maka terdakwa diputus bebas".

Oleh karena itu, perlu direkomendasikan kepada Tim Perancang KUHAP untuk perbaikan rumusan Pasal 191 ayat (1) dan (2) KUHAP

\section{Penutup}

Berdasarkan hasil peneltian dan pembahasan sehubungan dengan perumusan masalah, penulis dapat menarik kesimpulan sebagai berikut : Adanya pertimbangan dengan mempergunakan yurispudensi sebagai dasar hukum dalam menjatuhkan putusan pemidanaan diluar dakwaan Jaksa Penuntut Umm didasari beberapa alasan atau pertimbangan yaitu : 1) Alasan Filosofis : dipergunakannya yurisprudensi No. 1671/K/Pid./1996 tanggal 18-03-1997, oleh Majelis Hakim Pengadilan Tindak Pidana Korupsi sebagai dasar hukum dalam menjatuhkan putusan pemidanaan diluar dakwaan yang diajukan oleh Jaksa Penuntut Umum , karena isi pertimbangan hukum dalam yurisprudensi tersebut mempunyai tujuan yang sama dengan yang diinginkan oleh Majelis Hakim Pengadilan Tindak Pidana Korupsi yaitu dalam rangka mewujudkan keadilan dan kemanusiaan dalam masyarakat, yang juga telah relevan dengan asas hukum khususnya asas peradilan cepat, sederhana dan biaya ringan. Disisi lain apabila Hakim Pengadilan Tindak Pidana Korupsi yang memeriksa dan memutus perkara ini hanya menggunakan atau berpedoman pada isi Pasal 191 (1) KUHAP yang oleh karenanya membebaskan terdakwa, maka apa yang menjadi prinsip serta tujuan dari Penerapan Yurisprudensi Sebagai Dasar Hukum Dalam Memutus Perkara; 2) Alasan Yuridis, Adapun yang dijadikan sebagai alasan yuridis dipergunakannya Yurisprudensi MA No. 675 K/pid/ 1987, tgl 21-03-1989 oleh Majelis Hakim Pengadilan Tindak Pidana Korupsi dalam menjatuhkan putusan pemidanaan diluar dakwaan yang diajukan Jaksa Penuntut Umum dalam mengadili dan memutus perkara No. 17/PID.SUS/TPK/2014/PN.JKT.PST, adalah sebagai berikut :

1. Bahwa Yurisprudensi di Indonesia adalah merupakan salah satu sumber hukum yang dapat dipergunakan hakim sebagai dasar hukum, walaupun menurut hukum Indonesia, bahwa hakim adalah mandiri/otonom, tidak diwajibkan untuk mengikuti yurisprudensi yang ada. 
2. Bahwa sesuai dengan asas hukum yang ada yaitu Lex Specialis derogate Lex Generalis, maka sesuai dengan pemahaman serta penerapan dari asas ini, maka Majelis Hakim Pengadila Tindak Pidana Korupsi menerapkan Yurisprudensi MA No. $675 \mathrm{~K} / \mathrm{pid} /$ 1987, tgl 21-03-1989 dalam memeriksa dan memutus perkara No.

\section{7/PID.SUS/TPK/2014/PN.JKT.PST,} dengan pemahaman bahwa yurisprudensi adalah merupakan ketentuan yang bersifat khusus yaitu hanya mengatur hal tertentu yakni dalam hal pasal yang dipersalahkan masih sejenis dan lebih ringan dari pasal yang didakwakan oleh Jaksa Penuntut Umum dalam surat dakwaannya. Sedangkan ketentuan yang bersifat umum adalah sebagaimana ditentukan dalam Pasal 191 ayat (1) KUHAP.

3. Dalam penjelasan umum RKUHAP dikemukakan sejumlah indikator yang menunjukkan KUHAP sudah ketinggalan zaman. Pertama, KUHAP masih belum mampu memenuhi kebutuhan hukum dalam masyarakat, terutama dalam praktik penanganan perkara tindak pidana yang menjadi tugas para penegak hukum untuk menyelesaikan perkaranya secara baik dan adil. Kedua, perkembangan hukum dan perubahan peta politik yang dibarengi dengan perkembangan ekonomi, transportasi, dan teknologi yang global berpengaruh pula terhadap makna dan keberadaan substansi KUHAP.

Berkenaan dengan dasar hukum yang digunakan hakim dalam menjatuhkan putusan di luar pasal yang didakwakan oleh Penuntut Umum adalah melalui yurisprudensi MA No. 675 K/Pid/1987, tanggal 21-03-1989. Sementara itu, bila dilihat pada Pasal 182 ayat (4) dan Pasal 191 ayat (1) KUHAP, maka hukum acara pidana di Indonesia menyatakan bahwa putusan yang dijatuhkan hakim haruslah berdasarkan kepada surat dakwaan yang dibuat oleh Penuntut Umum. Jika pasal-pasal yang didakwakan Penuntut Umum dalam surat dakwaannya tidak terbukti di persidangan, maka terdakwa diputus bebas. Hal ini tentu menimbulkan kegamangan di dalam memahami hukum acara pidana di Indonesia.

Dalam subsistem pengadilan, praktek peradilan ditandai oleh kecenderungan meningkatnya disparitas (disparity) putusan pidana, seperti halnya Majelis Hakim yang mengadili suatu perkara tidak diwajibkan melaksanakan ketentuan yang tercantum dalam Pasal 191 ayat (1) KUHAP, akan tetapi dengan berpijak pada Yurisprudensi putusan MA No. 675 K/pid/ 1987, tgl 21- 
03-1989 sebagai dasar hukum telah menjatuhkan putusan berupa menyatakan bersalah serta menghukum terdakwa dengan putusan di luar dakwaan Jaksa penuntut Umum. Di lain pihak, juga terdapat yurisprudensi yang tidak memperkenankan penjatuhan pidana terhadap pasal yang tidak didakwakan, antara lain putusan Mahkamah Agung Nomor 321 K/Pid/1983, Nomor 47 $\mathrm{K} / \mathrm{Kr} / 1956$, dan Nomor 68 K/Kr/1973 yang menegaskan bahwa putusan pengadilan harus didasarkan pada surat dakwaan. Hal tersebut dapat menimbulkan disparitas terhadap perkara-perkara pidana yang sebenarnya hampir sama tetapi diputus oleh pengadilan-pengadilan yang berbeda karena diputus oleh dua model Yurisprudensi yang berbeda.

Oleh karena itu, perlu direkomendasikan kepada Tim Perancang KUHAP untuk perbaikan rumusan Pasal 191 ayat (1) dan (2) KUHAP, berdasarkan isi dari Yurisprudensi MA No. 675 K/Pid/1987, tanggal 21-03-1989. adalah sebagai berikut : "Jika yang terbukti adalah delict sejenis yang lebih ringan sifatnya dari delict sejenis yang didakwakan yang lebih berat sifatnya, maka meskipun delict yang lebih ringan tersebut tidak didakwakan, maka terdakwa dapat dipersalahkan dipidana atas dasar melakukan delict yang lebih ringan tersebut."

\section{DAFTAR PUSTAKA}

Achmad Ali. (1993) Menguak Tabir Hukum (Suatu Kkajian Filosofis dan Sosiologis), Penerbit : Chandra Pratama, Jakarta.

Ahmad Rifai. (2010) Penemuan Hakim oleh Hakim Dalam Perspektif Hukum Progresif, Penerbit : Sinar Grafika, Jakarta.

Bagir Manan. (2005) Hakim dan Pemidanaan, Majalah Hukum Varia Peradilan Edisi No. 249 Bulan Agustus 2006, Ikahi, Jakarta, 2006Horgan, John, The Psychology Of Terrorism,London and New York, Routledge.

Jazim Hamidi. (2005) Hermeunetika Hukum, Teori Penemuan Hukum Baru dengan Interpretasi Teks, Penerbit : UII Press, Yogyakarta.

Satjipto Rahardjo. (2007) Biarkan Hukum Mengalir, Catatan Kritis tentang Pergulatan Manusia dan Hukum, Jakarta: Penerbit Buku Kompas.

Sudikno Mertokusumo dan A. Pitlo (1993) Bab-bab Tentang Penemuan Hukum, Penerbit : Citra Aditya Bakti, Jakarta.

Soerjono Soekanto, Sri Mamudji. (2004) Penelitian Hukum Normatif Suatu Tinjauan Singkat, Penerbit: PT. Raja Grafindo Persada, Jakarta.

RBg (Rechtsreglement Buitengewesten )

Rv (Reglement op de Rechtsvordering)

Undang-Undang Dasar Negara Republik Indonesia Tahun 1945

Undang-Undang Nomor 8 Tahun 1981 tentang Kitab Undang-Undang Hukum Acara Pidana

Undang-Undang Nomor 48 Tahun 2009 tentang Kekuasaan Kehakiman 